\title{
Analysis of Gender Equality in Early Childhood Education in Indonesia
}

\author{
Sarah Zulkarnaini ${ }^{1, *}$, Vina Adriany ${ }^{2}$ \\ ${ }^{1,2}$ Early Childhood Education, School of Postgraduate. Universitas Pendidikan Indonesia, Bandung, Indonesia. \\ *Corresponding author.Email: sarahz@upi.edu
}

\begin{abstract}
This paper aims to discuss gender equality in early childhood education (ECE) institutions in Indonesia. Based on the existing literature, the authors argue that ECE institutions still maintain traditional gender views. The authors also assert that in order to overcome gender bias in the curriculum, ECE institutions need to develop two things, namely: gender awareness pedagogy and gender sensitive curriculum. Teachers also need to provide opportunities to children to play all types of games to children, without segregating them into male and female categories. The main results of this literature review highlight the importance of efforts to promote gender equality in ECE institutions in Indonesia.
\end{abstract}

Keywords: Equality, gender, early childhood education.

\section{INTRODUCTION}

The gender-equality discourse has long been launched. However, gender inequality still occurs, starting from the lowest level, namely during early childhood. Last year, millions of women in the Indian state of Kerala formed a $620 \mathrm{~km}$ long human chain "to speak out for gender equality", following a dispute over women's access to a famous Hindu temple there. The Sabarimala Shrine was historically closed to women of "menstrual age" between 10 and 50 years [1]. This happens because of gender imbalances in society. The most obvious problem is seen in the social situation, where women are marginalized from the public arena, such as the realms of politics, economy, and education. This is due to a gender gap that is increasingly evident [2]. Supported by other news delivered by katadata.co.id [3], and there is no guarantee of safety and comfort for women to do activities in public spaces.

In addition, Komnas Perempuan in CATAHU explained that the amount of violence against women in public spaces during 2020 was 3.602 cases. This is a sizable number. It can be traced that inequality, violence and discrimination are still mushrooming in society, especially in Indonesia, among which the problem is gender bias. Gender is a complex and dynamic set of ideas, actions, and feelings about what it means to be male or female in a particular place, culture, and time [4].

Ingraham [5] also emphasized that early childhood is the time when socialization informs gender, and early childhood can be seen as a starting point for gender socialization. The purpose of re-examining this gender issue is because the author sees that gender bias is increasingly emerging. Gender bias is a policy or discourse that prioritizes or harms one particular sex as a result of cultural regulations and beliefs. Gender bias in education is an educational reality that considers one particular gender to be superior, this results in gender inequality [6]. In addition, social learning theory shows that children will develop their behaviour based on their gender according to the expectations of others which reinforces their behaviour, and are encouraged not to develop behaviours that are considered culturally inappropriate [7]. Environment and culture greatly influence the gender construction process of a child, including the cultural environment at the formal education level.

However, before entering the formal education level, family and society are the main places where early childhood builds their gender identity. They get gender construction from their parents, environment, television, films, books, and illustrations [8]. In addition, teachers, culture, schools, peer groups, mass media, and other family members are figures and things that enable children to learn gender roles [9]. Many studies have shown a gender-equality discourse in early childhood education programs, both in games [10], in the education and the learning approach [11], in the learning model [12], and in the curriculum [13]. Based on the existing literature, the authors argue that gender equitable discourse for early childhood in the institution of early childhood education programs can be pursued in curriculum, teacher interaction and social environment, and games. 


\section{THE DISCOURSE OF GENDER- EQUALITY IN THE CURRICULUM}

So far there is no scientific data that states that men are born superior to women. Even in a study, intelligence tests showed that women obtained scores that were relatively the same as men [14]. Therefore, if there is an assumption that a certain gender is higher in strata, it is the result of a cultural construction that has the potential to give rise to other groups. Although there are also studies that show that there are differences in creative thinking skills that are differentiated by gender [15], however this cannot be generalized. The author assumes that every line in the world of education there are so many problems that arise so that there needs to be a reference for gender justice, namely in the curriculum.

In early childhood learning it is also necessary to develop learning that is oriented towards gender balance, by avoiding learning from gender-biased values, both in the field of developing behaviour formation and in the field of developing basic abilities [16]. This shows that there needs to be an effort to clearly include the concept of gender equity in the entire education process. The author assumes that by including the concept of gender in the curriculum in Indonesia it will be integrated into the entire educational process. So as to minimize gender bias that occurs in the institution of early childhood education, both by the system, teacher communication and other things.

To overcome gender bias in early childhood education, we need to pay attention to two things, namely gender awareness pedagogy and gender sensitive curriculum [17]. Gender-aware pedagogy means that teachers understand and are aware of gender which then becomes their attention in every action, interaction communication and policy. We understand more briefly so that every teacher's response to children is not gender biased. As stated by Roger, that a self-aware teacher can create awareness in students. Besides, related to gendersensitive curriculum, it can be understood that it is time for gender to be considered more deeply, covering the whole of education, by including it in the curriculum.

\section{GENDER EQUALITY DISCOURSE IN TEACHER INTERACTION AND THE SOCIAL ENVIRONMENT}

Many teachers of early childhood education think that gender issues are not important for early childhood, they are considered too quick to introduce complex problems such as gender to children [18]. Thus, in general there are very few practitioners in early childhood, in this case teachers, who actually try to challenge the tradition of gender stereotypes [17]. This shows that the teachers have the opportunity to carry out gender bias in teaching. This is because gender flexible teaching can only be practiced by teachers who are gender aware [19].
One of the developments in early childhood is social development. Corresponding to social development is the formation of one's own gender. As children grow up, cultural codes of femininity and masculinity are strengthened and contested by the compilation of children who are assisted by their social environment [20]. Every day, it will train children to respond to their gender. Children will determine their response to the influences that enter their daily lives, and they will develop their gender roles through this response [21]. The response that occurs is understood as an interaction. Verbal interactions are not the only interactions; nonverbal interactions with other children and with teachers that greatly influence communication competence and making intersubjective meanings.

There is one interesting study, namely deGroot Kim's research [21] where there is a document that shows that boys accidentally construct gender through nonverbal, boys do wrestle in front of the door while waiting for the break. Unfortunately, whenever this happens, the teacher asks the boy to come out first while the girls wait. Inadvertently the teacher is displaying a gender bias against all the children in the class. The gender message that was conveyed was that girls waited in class, and boys could go out first.

Often teachers instil certain values related to children's identities, such as the categories of boys and girls [22]. Teachers are expected to create an environment where children can observe and absorb messages about a fairer gender. In this regard, Blaise [23] suggests that teachers need to expand their knowledge by promoting gender critical awareness in children by challenging or destroying masculine norms and starting to foster equality between boys and girls in educational institutions, including in early childhood education programs. The author proposes that realizing gender justice is by facilitating fostering understanding of gender and providing direction for gender reflection to teachers. The hope is that the practice of gender fairness is reflected in his actions after it becomes his own person. So that in social and interaction, the teacher will consciously construct gender equity in early childhood.

\section{GENDER-EQUALITY DISCOURSE IN GAMES}

Researchers on play agree that play is powerful against gender development. From eighteen months to three years of age, young children are involved in parallel play where activities are involved side by side [24]. No wonder every activity of these children is all in the form of play. Blackfort explained that in the 19th century the middle class began building playgrounds as a struggle to develop children's development and to teach gender skills through games and activities. Exactly in the same year, namely 1930, also known as the slogan of children's 
rights, is play. As the line of life develops, the game also continues to experience progress and innovation.

Research on play shows that play has a large impact on children's gender construction. Games provide critical development opportunities to foster how children can formulate new meanings that they compile so that they are balanced at home and at school [25]. Children play with gender meanings, play roles in different categories, and build their own gender identity.

Gender is the result of social construction, so that the impact is in accordance with the construction. There is also a negative potential for play in the realm of gender, including the dominance of the power of masculinity built by boys in games, so that boys who do not show masculine are categorized as boys who fail [23]. Then Chase [26] also shows how boys can access more football games, trucks and racing cars. Meanwhile, women had more opportunities for dolls, kitchen, pony games. This gives boys and girls different play opportunities. Certainly, shows a gender bias.

In addition, there is an expectation for girls to be more inclined to play towards regular games while boys are expected to be more inclined towards irregular play [27]. Children also learn when socializing with peers or adults, during play learning activities in early childhood education, through imitating and assimilating from behavioural attitudes and tangible concepts obtained by children [10].

However, based on some literature, there is something interesting about technology education. Several activities and themes in early childhood education can be used as further conversation for educational purposes. The reason is that Turja et al. [13] analysed that the curriculum of the early childhood education program generally does not include specific guidelines to ensure the equality of boys and girls. However, the technology education that is proposed is expected to pay attention to gender roles. It is further explained that to provide equal opportunities for boys and girls to play all kinds of games that lead to technology, with the aim of maintaining equal interest in boys and girls [13].

In summary, if we want to understand how gender discursively regulates children's feelings about themselves, then we can analyse how each dimension works in their lives, this can be seen from children's attitudes, gestures or styles [19]. For example, the way children stand, perceive, and give conditions to reveal gender characteristics and how they struggle to get things as gender creatures. The author proposes that for a gender-equality discourse on games, adults, especially teachers, do not classify certain games. Every child has the right to play the games they want without any social construction affecting them, so that playing opportunities can facilitate children's interest.

\section{DISCUSSION}

Based on the basis of the Indonesian State, namely Pancasila and the 1945 Constitution as described in the introduction, the State should guarantee justice for its people. If it is carried out according to the basis of the State, there will be no more discrimination, violence, oppression, fraud, crime, intimidation and so on. In terms of education, the basis of this State can be a reference for achieving educational goals, starting from the lowest education, namely early childhood education, one of which is by paying attention to gender justice. This effort is expected to minimize the existence of marginalized groups. School power must play an active role in realizing gender equity in formal early childhood education institutions.

To emphasize even more, gender justice can be realized by eliminating discrimination between women and men [28]. Gender justice means that there is no standardization or specificity of roles, multiple burdens, marginalization, subordination or violence against men and women [6]. Marpinjun and Ramsey's research [29] shows that the importance of reflection is done by adults, especially teachers, because through reflection, especially critical reflection, someone will understand the gender problems that have been carried out, it could be by distinguishing colours or icons in male or female students or other. It is hoped that the teacher understands the imbalance that is being carried out, so that in the process of learning and / or playing the teacher is more gender equitable to children, especially early childhood.

\section{CONCLUSION}

The findings of this paper reveal things that are generally still gender biased in the scope of early childhood education. Gender problems play out in the realm of early childhood education, starting from the curriculum, teacher and social interactions to games. Gender is no stranger to being a dilemma for practitioners of early childhood education programs. So it is time to realize together to try to destroy the culture of gender bias in early childhood education which has been in the chain.

A gender justice that is wanted to be achieved in sustainable development is the guarantee of comprehensive access to education, health services and the economy. It should be emphasized that biological differences cannot be used as a measure for discrimination on educational, socio-political, cultural, legal, economic and defence and security rights [5]. Based on the existing literature, the author proposes three points on gender-equality discourse in early childhood education institutions, including gender-equality discourse on the curriculum, social environment interactions and games. 
Based on the existing literature, the author proposes three points on gender-equality discourse in early childhood education institution in Indonesia, including gender-equality discourse in the curriculum, teacher interactions and the social environment, and games.

\section{REFERENCES}

[1] BBC News Indonesia. Tiga juta perempuan India bentuk rantai manusia sepanjang $620 \mathrm{~km}$ untuk "kesetaraan gender." BBC News Indonesia [Internet]. 2019 January 2. Available from: https://www.bbc.com/indonesia/majalah-46733533.

[2] Mas'oed M. Ekonomi politik internasional dan pembangunan. Yogyakarta: Pustaka Pelajar; 2003.

[3] Bayu DJ. Nasib buruh perempuan, alami diskriminasi di seluruh sektor industri. Berita Katadata [Internet]. 2019. Available from: https://katadata.co.id/yuliawati/berita/5e9a5520d18 98/nasib-buruh-perempuan-alami-diskriminasi-diseluruh-sektor-industri.

[4] Archer L. Race, masculinity and schooling: Muslim boys and education. London: Open University Press; 2003.

[5] Ingraham C. The heterosexual imaginary: Feminist sociology and theories of gender. Sociological Theory. 1994;12:203-19.

[6] Asrohah H. Sosiologi pendidikan. Surabaya: Kopertais Press; 2008.

[7] Bank JB(Ed.). Gender and education: An encyclopedia (Vol.I\&II). London: Praeger Publication; 2007.

[8] Gosselin C. Philosophy and the role of teacher reflections on constructing gender. Educational Foundations. 2007;21(3-4):39-57. Available from: http://web.njcu.edu/sites/edfoundations/Content/def ault.asp.

[9] Santrock, JW. Perkembangan anak edisi 7 jilid 2. (Terjemahan: Sarah Genis B) Jakarta: Erlangga; 2011.

[10] Putri RD. Budaya adil gender pada pendidikan anak usia dini melalui permainan peran. Jurnal Wahana Konseling. 2019;2(2):74-83.

[11]Utomo SS, Ekowati U, Sosial P, Dini AU, Studi, P, Sejarah $\mathrm{P}$, et al. Pendidikan responsif gender bagi anak usia dini. 2019;3(1):51-60.

[12]Dewi SM. Pengembangan model pembelajaran responsif gender. 2013;1:119-34.

[13] Turja L, Endepohls-Ulpe M, Chatoney MA. Conceptual framework for developing the curriculum and delivery of technology education in early childhood. International Journal of Technology and Design Education. 2009;19(4):353-65.
Available from: https://doi.org/10.1007/s10798009-9093-9.

[14]Zaduqisti E. Stereotip Peran gender bagi Pendidikan Anak. Jurnal Muwazah. 2009;1:73-82.

[15]Marzuki AECM, Wahyudin. Creative thinking ability based on learning styles reviewed from mathematical communication skills. Journal of Physics: Conference Series. 2019;1315(012066):111. Available from: https://doi.org/10.1088/17426596/1315/1/012066.

[16] Shobahiya M. Pembelajaran berperspektif gender dalam Islam untuk anak usia dini. Suhuf. 2012;24(1):39-50. Available from: http://hdl.handle.net/11617/2913.

[17] Warin J, Adriany V. Gender flexible pedagogy in early childhood education. Journal of Gender Studies. 2017;26(4):375-86. Available from: https://doi.org/10.1080/09589236.2015.1105738.

[18] MacNaughton G. Rethinking gender in early childhood education. Sydney: Allen \& Unwin; 2000.

[19] Hogan V. Locating my teaching of gender in early childhood education teacher education within the wider discourse of feminist pedagogy and poststructuralist theory. In Education and AsiaPacific Educational Research International Conference (AARE-APERA 2012). Sidney; 2012 Dec. Available from: https://files.eric.ed.gov/ fulltext/ED542504.pdf.

[20] Goncu A. Development of intersubjectivity in the dyadic play of preschoolers. Early Childhood Research Quarterly. 1993;8(1):99-116.

[21] De Groot Kim S. Lessons learned early: Girls wait. In: Jacobsen $\mathrm{T}$, editor. Perspectives on gender in early childhood education. Saint Paul, MN: Redleaf Press; 2011:pp.231-246.

[22] Ryan S, Grieshaber S. Shifting from developmental to postmodern practices in early childhood teacher education. Journal of Teacher Education. 2005;56(1):34-45.

[23] Blaise M. Gender discourse and play. In: Brooker E, Blaise M, Edwards S, editors. Handbook of Play and Learning in Early Childhood. London: SAGE; 2014:pp.115-27.

[24] Garvey C. Play. Cambridge: Harvard University Press; 1990.

[25] Johnson J, Christie C, Wardle F. Play, development, and early childhood. Boston: Pearson; 2005.

[26] Blaise M. Playing it straight. New York: Routledge; 2005.

[27] Chase CM. Children's play: The construction of gender roles. Young Children. 2009;1(21):83-6. 
[28]Fabes RA, Hanish LD, Martin CL. Children play: The role of peers in understanding the effect of child care. Child Development. 2003;74(4):1039-43.

[29] Marpinjun S, Ramsey PG. Feminism and Early Childhood Education in Indonesia: Teachers' Reflections. In: Smith K, Alexander K, Campbell $\mathrm{S}$, editors. Feminism(s) in Early Childhood. Perspectives on Children and Young People. Singapore: Springer; 2017. 